\title{
Impact of human activities on Cross River gorilla Gorilla gorilla diehli habitats in the Mawambi Hills, southwest Cameroon
}

\author{
Denis Ndeloh Etiendem ${ }^{1,2, *}$, Nikki Tagg ${ }^{2,3}{ }^{,}$Luc Hens $^{4}$, Zjef Pereboom ${ }^{2}$ \\ ${ }^{1}$ Human Ecology Department, Vrije Universiteit Brussel, Laarbeeklaan 103, Brussels 1090, Belgium \\ ${ }^{2}$ Centre for Research and Conservation, Royal Zoological Society of Antwerp, Koningin Astridplein 26, \\ Antwerp 2018, Belgium \\ ${ }^{3}$ Projet Grands Singes (PGS), BP 5619 Nlongkak, Yaoundé, Cameroon \\ ${ }^{4}$ Vlaamse instelling voor Technologish Onderzoek NV (VITO), Roderveldlaan 5, Antwerp 2600, Belgium
}

\begin{abstract}
Most forest habitats in Cameroon support villages whose inhabitants are heavily reliant on the forests for their everyday needs. We assessed the socio-economic status and natural resource use of 3 villages bordering Mawambi Hills, an unprotected forest in southwest Cameroon, home to both the Critically Endangered Cross River gorilla Gorilla gorilla diehli and the Endangered Nigeria-Cameroon chimpanzee Pan troglodytes ellioti. This forest likely hosts one of the largest sub-populations of Cross River gorillas in Cameroon and is vulnerable to human influence given that it lies in close proximity to surrounding villages and is less hilly than other Cross River gorilla habitats. We show that employment opportunities in surrounding villages are rare, and people rely on agriculture and the collection of non-timber forest products (NTFPs), such as eru Gnetum spp. and bush mango Irvingia spp., for food and income. We also show that areas of heavy human activity coincide spatially with great ape nest sites and raise concerns about the potential impact of human activities on great ape survival at the site. We call for (1) sustainable harvesting and marketing of NTFPs, (2) the introduction of alternative livelihood opportunities (e.g. beekeeping and on-farm production of NTFPs), (3) active wildlife law enforcement to safeguard the persistence of great apes, and (4) the introduction of a community-based forest management programme that will enable communities to secure the rights to use and manage surrounding forest resources legally.
\end{abstract}

KEY WORDS: Non-timber forest products · NTFP · Gnetum spp. · Forest management $\cdot$ Non-wood forest products $\cdot$ Irvingia spp. $\cdot$ Cross River gorilla $\cdot$ Chimpanzee

\section{INTRODUCTION}

The commercial trade in forest resources is important for forest-living communities throughout the world (Ames 1999, Ticktin 2004, SCBD 2011). More than $80 \%$ of people who live in tropical forests harvest wild plants and animals for food and income (Lahm 2001). In the Congo Basin, wild meat remains the primary source of animal protein for local people, who consume on average 4.9 million $\mathrm{t} \mathrm{yr}^{-1}$ (Fa et al. 2002). For most forest-living communities, non- timber forest products (NTFPs) either serve as the main source of income or act as an important safety net during seasons of low agricultural output (Ingram et al. 2012). In Cameroon, some 500 plant species and at least 85 animal species constitute the NTFPs utilised by rural people (Ingram et al. 2012). Markets for NTFPs have a total annual value in sales of approximately US\$21 872000 (Aveling 2009). A typical example of a valuable NTFP in this region is Gnetum spp. (for example, G. africanum and G. buchholzianum), a dioecious forest vine commonly known in 
Cameroon as 'eru' (English) or 'akok' (French), whose leaves are intensively exploited as a foodstuff in lowland forests throughout the Congo Basin. Eru leaves are ranked among the 10 most valuable NTFPs in the Congo Basin (Ingram \& Schure 2010). With an annual market value of US\$12 million, eru is the third most valued NTFP in Cameroon after fish and fuelwood and contributes an average of $62 \%$ of a harvester's annual income (Ingram \& Schure 2010, Ingram et al. 2012). In addition to commercial and food uses, eru is also reported to be used for medicinal purposes (Jiofack et al. 2008). Other valuable NTFPs in Cameroon are bush-meat (small to large-sized mammals, ungulates, reptiles, and rodents), bush mango Irvingia gabonensis and I. wombolu, njangsang Ricinodendron heudeloti, and hausa sticks Carpolobia lutea and C. alba (Ingram et al. 2012). The kernels of bush mango are highly valued as a cooking ingredient/ thickening agent and form an important part of the West and Central African diet (Ainge \& Brown 2004). The seeds of njangsang are valued for their distinctive flavour and are ground and used as flavouring and thickening agents in food (Plenderleith 2004). The extremely hard, termite-resistant stems of Carpolobia spp. (hausa sticks) are principally used for cattle control by Hausa and Fulani herdsmen in neighbouring Nigeria (Sunderland et al. 2002).

When done sustainably, exploitation of NTFPs can enhance livelihoods and the economic development of rural populations and also contribute to conservation objectives (Michon \& de Foresta 1997). Indeed, NTFP exploitation is a more financially favourable option in the long term than other more destructive types of land use, such as commercial logging (Peters 1994, Arnold \& Ruiz Pérez 2001). Unfortunately, growing human populations and the rising demand for NTFPs are leading to increased pressure on natural resources (Ingram \& Schure 2010). Current NTFP exploitation rates appear to be unsustainable throughout Central Africa and some natural resources may soon disappear completely through intensive harvesting that affects species survival, growth and reproduction rates and can disrupt ecosystem functionality (de Merode et al. 2004, Ticktin 2004).

The causes and consequences of unsustainable NTFP exploitation are largely debated (Arnold \& Ruiz Pérez 2001). Benefits derived from the collection and sale of NTFPs differ among user groups and usually increase with distance from the forest interior (Ingram et al. 2012). Communities associated with NTFP collection are mostly located in remote areas with poor socio-economic conditions and a lack of sufficient infrastructure, transportation and health services (Kar
\& Jacobson 2012). As a result of these physical and institutional barriers, the sale of NTFPs only provides basic household income and thus is unlikely to contribute much to poverty alleviation. Insufficient revenue-generation from NTFP collection in forestliving communities often results in more intense harvesting of wild plants (Ikpa et al. 2009), which has generated concerns about over-exploitation and represents a threat to the local wildlife (Boot \& Gullison 1995, Willcox \& Nambu 2007). In addition, improved access to previously inaccessible remote forest areas could cause rapid depletion of forest resources and disruption of forest ecosystems, unless conservationcompatible livelihood opportunities are developed and local people are actively engaged in resource management (Kar \& Jacobson 2012).

The effect of human disturbance on a mammal community depends on the species' ecology and on the spatio-temporal scale of disturbance (Blom et al. 2004, Dumbrell et al. 2008, Stokes et al. 2010). For slow-reproducing, large-bodied species such as gorillas and chimpanzees, survival prospects worsen with increasing human disturbance (Fa et al. 2005, Morgan \& Sanz 2007). Consequently, these species are at greater risk of extirpation in heavily disturbed areas than fast-reproducing, small-bodied species (Oates et al. 2000, Remis 2000, Kümpel 2006).

The Cross River gorilla (CRG) Gorilla gorilla diehli is listed as Critically Endangered on the IUCN Red List (Walsh et al. 2008; see www.redlist.org). The entire CRG population is thought to comprise $<300$ individuals fragmented across 12 to 14 hilly enclaves along the Nigeria-Cameroon border (Nicholas et al. 2010). The Nigeria-Cameroon chimpanzee (NCC) Pan troglodytes ellioti is listed as Endangered on the IUCN Red List and is considered the most threatened of all chimpanzee subspecies, numbering possibly as few as 3500 animals (Morgan et al. 2011; see www.redlist.org). Hunting of CRG and NCC in the region has fallen considerably over the last decade partly because of increased conservation outreach and the presence of researchers (Oates et al. 2007). Nevertheless, efforts to protect remaining populations are constrained by intensive bush-meat hunting, the expansion of farmland, and forest-exploitation activities of surrounding village communities (Oates et al. 2004). In the absence of effective management strategies, the continuing expansion of human activities in these areas has the potential to further fragment remaining great ape habitats, preventing migration between sites. This is likely to alter ape ranging patterns, increase psychological stress, and prevent dispersion and interbreeding between 
isolated sites (Oates et al. 2007, Morgan \& Sanz 2007, Boesch 2008). Additionally, habitat changes due to human activities can alter parasite-host dynamics and influence the population trajectories of ape species (Gillespie et al. 2005).

In the present study, we describe the socio-economic status of 3 villages (Awuri, Assam, and Takpe) located in an unprotected CRG and NCC forest habitat called Mawambi Hills (MH) and quantify their spatial and temporal use of forest resources to assess (1) the extent to which villagers at this site rely on forest resources and (2) the potential impact of human activities on great ape populations. We contribute to the current understanding of natural resource use by rural African populations, expose the challenges faced in managing human-wildlife co-existence in unprotected forests, and make recommendations on how to balance human needs with the conservation of great apes in unprotected forests. Though information is scarce regarding the socio-economic status of communities living in great ape habitats in this region and on the type, intensity, and extent of resource exploitation, such knowledge could help conservation management. The IUCN regional action plans for the conservation of CRG and NCC recommend an understanding of village socio-economic status and an investigation of potential alternative livelihood options (Oates et al. 2007, Morgan et al. 2011). Preliminary research on the socio-economic status of $>31$ villages around the Takamanda National Park (TNP), including the study villages, was obtained prior to creation of the park in 2009 (D. A. Agbor unpubl. rep., M. Mdaihli et al. unpubl. rep.). However, although this information addressed the demographics, economic activities, infrastructure, and social systems of villages, it was broad in context, and the results did not clearly describe patterns of human utilisation of important forest areas bordering the park, such as $\mathrm{MH}$.

\section{MATERIALS AND METHODS}

\section{Study site}

The focal communities are typically small, rural livelihood-based settings, located in close proximity $(<0.5 \mathrm{~km})$ to $\mathrm{MH}$ at the southeast border of TNP $\left(9^{\circ} 0^{\prime} \mathrm{E}\right.$ and $6^{\circ} 0^{\prime} \mathrm{N}$; Fig. 1); they retain local traditional rights of access and forest use. The villagers are of the Anyang tribe and speak a local language called Denya. The population of the 3 villages combined is close to 400 residents. In Table 1, we present information on the accessibility, housing, and availability of social service infrastructure, which together generally suggest poor living conditions. MH has no legal management status and is classified as 'communal forest' under the Cameroon land-use planning system (decree no. 95/531/PM of 23 August 1995 accompanying the Cameroon forest law no. 94/01 of 20 January 1994). Under this plan, NTFP collection and subsistence hunting of unprotected species is allowed. Both gorillas and chimpanzees are protected under this law, and hunting is prohibited, although implementation of the law is largely ineffective (Scholte 2009).

Most of the forest at $\mathrm{MH}$ lies between 100 and $300 \mathrm{~m}$ above sea level (a.s.l.) and can generally be classified as lowland forest. In most places, the forest is secondary in nature, probably as a result of many generations of shifting cultivation (Bergl et al. 2007).

Fig. 1. Location of Mawambi Hills study site (red outline), southwest Cameroon, showing village location (red dots), and surrounding land-use types

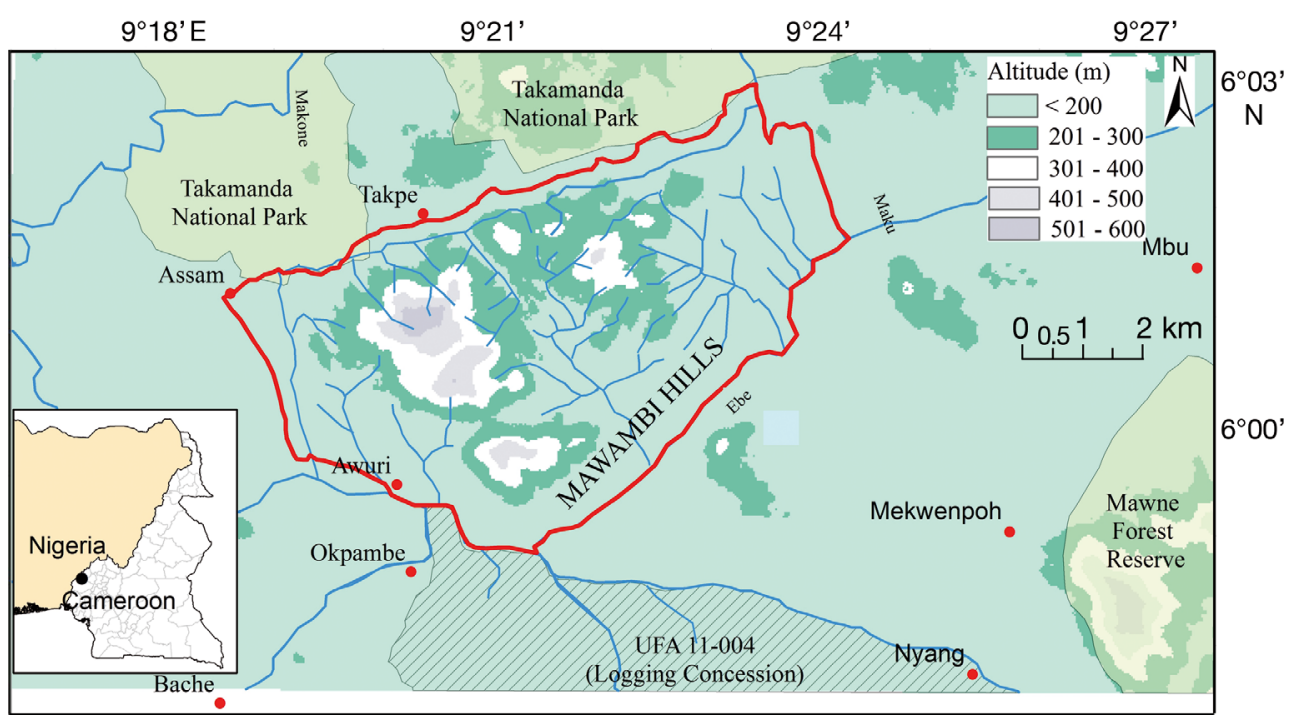


Table 1. Current socio-economic conditions of 3 villages bordering Mawambi Hills, southwest Cameroon (data from 2010)

\begin{tabular}{|ll|}
\hline Socio-economic condition & Local measurement \\
\hline Education & \\
Number of primary schools & 1 \\
Number of secondary schools & 0 \\
Average distance to nearest primary school $(\mathrm{km})$ & 3.5 \\
Transportation and accessibility & \\
General road access & Seasonal ${ }^{\mathrm{a}}$ \\
Distance to nearest paved road (km) & $48^{\mathrm{b}}$ \\
Distance to the nearest food market $(\mathrm{km})$ & $48^{\mathrm{b}}$ \\
Health and sanitation & \\
Distance to nearest public pipe-borne water supply $(\mathrm{km})$ & 48 \\
Total number of toilets or latrines in all villages & 0 \\
Main source of cooking and drinking water & Forest streams \\
Main source of bathing water & Forest streams \\
Method of sewage disposal & Streams \& bushes \\
Materials used in house construction (wall and roof type; $\mathbf{n}=\mathbf{5 3}$ house- \\
holds) (\%) \\
Mud blocks \& zinc & 27.8 \\
Mud walls/sticks \& zinc & 13.9 \\
Mud blocks \& thatch & 23.6 \\
Mud walls/sticks \& thatch & 34.7 \\
aRoads are impassable during the rainy season & \\
bamfe, located south of the villages, is the nearest urban/commercial centre \\
\hline
\end{tabular}

It also supports many species characteristic of old secondary growth, such as Piptadeniastrum africanum, Vitex grandifolia, Treculia obovoidea, and $\mathrm{Mu}$ sanga cecropioides. Between 301 and 600 m a.s.l., the forest is characterized by vegetation growing on the sides and ridges of rocky hills (lowland ridge forest). These hilly and sometimes near-vertical ridges support many stands of large trees, including species of commercial value, such as Terminalia ivorensis (framire), T. superba (fraké), and Lophira alata (azobé), interspersed with patches of natural grasses and herbs growing on cliffs. An active logging concession (UFA 11-004) lies on the other site of the Ebe (Munaya) River that forms the southeast limit of MH. To the northeast, $\mathrm{MH}$ is connected to the TNP via an unofficial, unprotected forest corridor.

The climate is bi-seasonal and pseudo-equatorial, characterized by a dry season $(<100 \mathrm{~mm}$ of rain) that typically lasts 5 mo (November to March) and a rainy season peaking in the months of August and October. Mean annual rainfall in 2009 and 2010 was $2744 \mathrm{~mm}$ (range 2359 to $3129 \mathrm{~mm}$ ) at the BesongAbang weather station south of the study area. Temperature varies little over the year, with an average of $27.4^{\circ} \mathrm{C}\left(22.2\right.$ to $\left.33.2^{\circ}\right)$.

Of the 11 known CRG populations in Cameroon, the unprotected $\mathrm{MH}$ may hold one of the largest groups, estimated to be between 20 and 30 animals in a $43 \mathrm{~km}^{2}$ area (D. N. Etiendem pers. obs.). A small population of the endangered NCC is also found in this forest in addition to other primates of conservation importance (a full list of primates present at $\mathrm{MH}$ is shown in Table $\mathrm{S} 1$ in the supplement at www.int-res.com/articles/suppl/ n020p167_supp.pdf) and is therefore an important site for the survival of endangered great ape subspecies.

\section{Questionnaire survey}

An interviewer-administered questionnaire survey, designed to assess household $\mathbf{1}$ socio-economic and livelihood activities during the planting, harvesting, and hunting season of 2009 was conducted during a 2 wk stay in the villages (28 July to 10 August). The interviews were designed to obtain information on household size, relative importance of different sources of income, farming activities, involvement in the harvesting of various NTFPs, destination of harvested NTFPs (household consumption or sale), hunting with snares and shotguns, and livestock ownership (see Supplement 2 at www.int-res.com/articles/suppl/ n020p167_supp.pdf). The field team was composed of the first author accompanied by a local assistant. Interviews were conducted with household heads, but other members of the household were often present and contributed to responses. A total of 53 out of 57 households were surveyed once, resulting in a sampling intensity of $93 \%$. The remaining $7 \%$ of households were not surveyed because household heads were not present in the village during the survey period. At the beginning of each interview, informants were briefed on the subject and objectives of the research. Interviews were conducted in Cameroonian Pidgin (a language used in Englishspeaking regions of Cameroon); they took $\sim 30 \mathrm{~min}$ each and were held in the evening to avoid disruption of daily activities. The household head was male in $75.6 \%(n=40)$ of the households surveyed. Other

${ }^{1}$ Household refers to a group of people sharing the same kitchen or cooking space 
interviewees were widows or single women. The total population of the sampled households was 350 residents.

\section{Measuring human activities}

Field surveys were conducted between January and December 2010 to record signs of human activities within $\mathrm{MH}$. Prior consultation with 10 hunters revealed that human activities were mostly carried out along established hunting trails. Therefore, major hunting trails connecting the 3 villages (a total of $35.8 \mathrm{~km}$ ) were identified, and each trail was monitored once a month for 12 mo. The locations of signs of human activity (hunting [spent cartridges and active wire snares], harvesting of NTFPs, illegal timber extraction, hunting camps, and farms) visible from these trails were recorded using a Garmin 60CSx GPS unit. During the same period, signs of human activity were also recorded opportunistically in other parts of $\mathrm{MH}$ while searching for signs of great ape presence. When an active snare line was encountered, the line was walked, snares were counted, and GPS locations were recorded. Care was taken to distinguish old from new hunting signs (e.g. all spent cartridges were removed to avoid recording them again the following month). Machete cuts were not recorded because machetes were sometimes used by researchers and were not necessarily indicative of village-level activities.

\section{Great ape nest sites}

Great ape nest sites were sought during targeted gorilla surveys conducted between July 2009 and September 2011, for a total of 297 survey days (mean number of days per month: 13; range: 6 to 25). On a monthly basis, the research team searched the forest for indirect signs of gorilla and chimpanzee presence (e.g. vegetation trails, food trails, prints, and dung deposits) with the assistance of local hunters. When encountered, a nest-site location was recorded with a GPS unit. Gorilla nest sites were distinguished from chimpanzee nest sites by the presence of fresh gorilla dung.

\section{Data analysis}

Initial exploratory analyses of the questionnaire data indicated negligible differences in responses among the 3 villages; consequently, all data were pooled. To understand the spatial distribution of human activities within the study area, a kernelsmoothed intensity function as provided in the $\mathrm{R}$ package SPATSTAT (Baddeley \& Turner 2005) was used to fit first-order (mean number of points per unit area) intensities of the locations of different human activities. The smoothing bandwidth was selected using a cross-validation method. Point locations of gorilla and chimpanzee nest sites were overlaid on the resulting density map to access spatial congruence between human activities and great ape nestsite locations. The output was visualized in ArcGIS 9 (v9.3.1). We used R (v2.14.1), and Excel (v9) for all analyses.

\section{RESULTS}

\section{Human demographics and livelihoods}

Average household size was 7 persons (range: 1 to 17 ), and the average age of household heads was 41 yr (range: 24 to $65 \mathrm{yr}$ ). All household heads were natives. Agriculture and NTFP extraction were mentioned among the top 3 sources of income by $96 \%$ and $51 \%$ of households, respectively. Average household farm size was 0.99 ha ( 0.5 to 6.5 ha; $\mathrm{SD}=0.73$ ), and average duration of farming was $11 \mathrm{yr}$ (1 to $40 \mathrm{yr}$; $\mathrm{SD}=9.4$ ). Major crops cultivated included oil palm Elais guineensis, cassava Manihot spp., cocoa Theobroma cacao, cocoyam Xanthosoma sagittigolium, banana Musa spp., egusi Citrullus vulgaris, and plantain Musa paradisiaca. Except for cocoa, most agricultural products $(69 \%)$ were used by households for non-commercial purposes (Fig. 2).

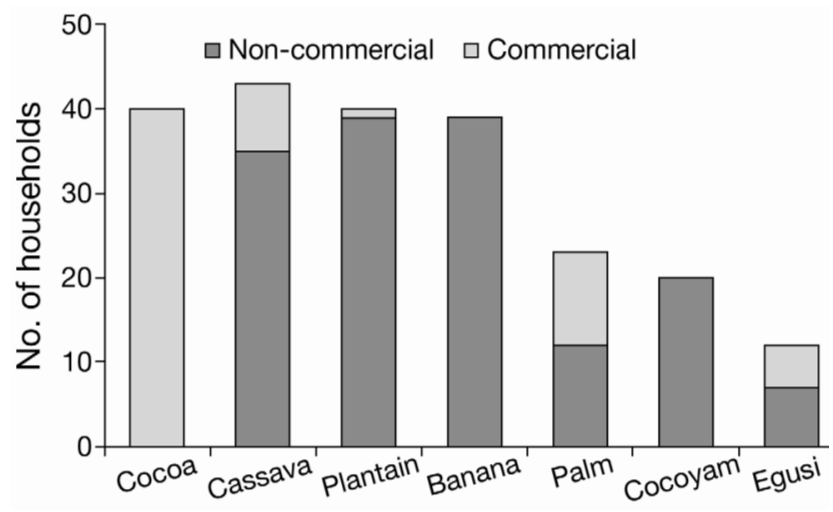

Fig. 2. Crops cultivated and used or sold by households $(\mathrm{n}=53)$ in study villages at Mawambi Hills, southwest Cameroon 


\section{NTFP harvesting}

NTFP collection was a common activity. A total of $78 \%$ of the households were involved in the collection of 3 species: eru Gnetum spp., bush mango Irvingia spp., and njangsang Ricinodendron heudelotii. When considering all non-animal NTFPs, only $21 \%$ of harvested products are consumed.

Eru was collected in large quantities and very regularly. Forty percent of households were actively involved in the collection of eru leaves. A typical eru harvester is a middle-aged woman, married with 3 to 7 children, mostly uneducated, and visiting the forest 1 to 3 times each week for the harvest. During weekends and holidays, students also accompany their relatives to the forest for the harvest. Collectors reportedly earned 150 FCFA (US\$ $0.3^{2}$ ) per $\mathrm{kg}$ of eru leaves.

Regarding other NTFP collection, $92 \%$ of the households said they usually participate in bush mango collection during the fruiting season that lasts from July to August each year. During the study period, it was reported by villagers that 325 bundles of hausa sticks were harvested from MH by non-indigenous Hausa and Fulani men from Nigeria who pay the village community for their harvests. A full list of the NTFPs harvested from $\mathrm{MH}$ and their principal uses are presented in Table $\mathrm{S} 2$ in the supplement at www.int-res.com/articles/suppl/n020p167_supp.pdf.

\section{Hunting}

Fig. 3 shows the 7 most commonly hunted animal species or group of species. Duikers were reported as

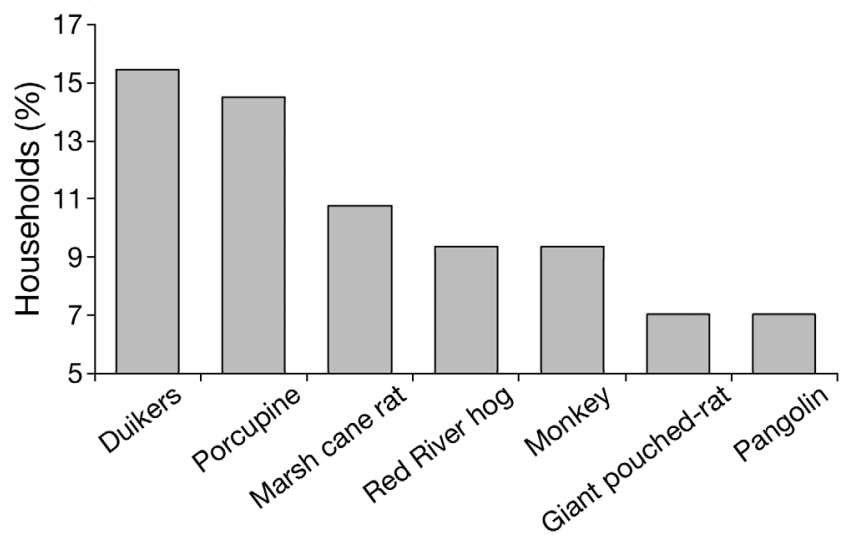

Fig. 3. Animal species or groups of species hunted at Mawambi Hills, southwest Cameroon, deduced from household surveys of hunting in 2009

${ }^{2}$ US\$ 1 was equivalent to 502 FCFA at the time of the study the most hunted species (hunted by $21 \%$ of the households). This was followed by porcupines $(19.5 \%)$, giant rats $(14.2 \%)$, and monkeys $(13.8 \%)$. However, differences in the rate of hunting of different animal species were not statistically significant $\left(\chi^{2}=24.33, \mathrm{df}=6, \mathrm{p}>0.05\right)$. The number of animals hunted per household per month ranged from 1 to 20 (mean 3.85; $\mathrm{SD}=4.25$ ). Hunting and snaring requires walking long distances and spending nights in the forest, an activity exclusively carried out by men. In $20 \%$ of the households, hunting or trapping was mentioned as the primary source of income. Snaring was the principal method employed for bush-meat hunting ( $35 \%$ of snare hunters versus $21 \%$ of gun hunters). A total of 23 snare hunters reported setting an average of 109 wire snares each in 2009 (total 2062 snares, range: 25 to 300). On average, each hunter recovered 4.15 (range: 1 to 20) animals from snares each month during the 5 mo trapping season that began in June. Hunters reported visiting their snares on average every $2.65 \mathrm{~d}$ (range: 1 to $3 \mathrm{~d}$ ). Eighty percent of the hunters said bush-meat is harvested for commercial purposes, while $20 \%$ said bush-meat is harvested for both sale and local consumption. The main market for bush-meat is in Mamfe, the nearest commercial town. However, with improved road access, some traders come to the villages to buy bush-meat.

\section{Livestock}

Only $11(21 \%)$ of the households kept sheep (a total of 39 animals), and $24(45.3 \%)$ households kept chickens (a total of 153 birds). Whilst most livestock $(90 \%)$ is sold rather than consumed, livestock rearing is not intensive and therefore contributes little to household income.

\section{Spatial distribution of human activity and great ape signs}

A total of 1224 human-activity signs were recorded within $\mathrm{MH}$ during the study period. These included 438 spent cartridges, 662 active wire snares, 48 signs of eru harvesting, 61 cases of illegal timber extraction, and 15 hunting camps. The mean monthly encounter rate of human activity along hunting trails was $2.85 \mathrm{~km}^{-1}$ (range: 1 to $3 \mathrm{~km}^{-1}$ ). The spatial distribution of human activity signs varied considerably (Fig. 4), with the central-southern part of the forest close to Awuri village experiencing the highest den- 

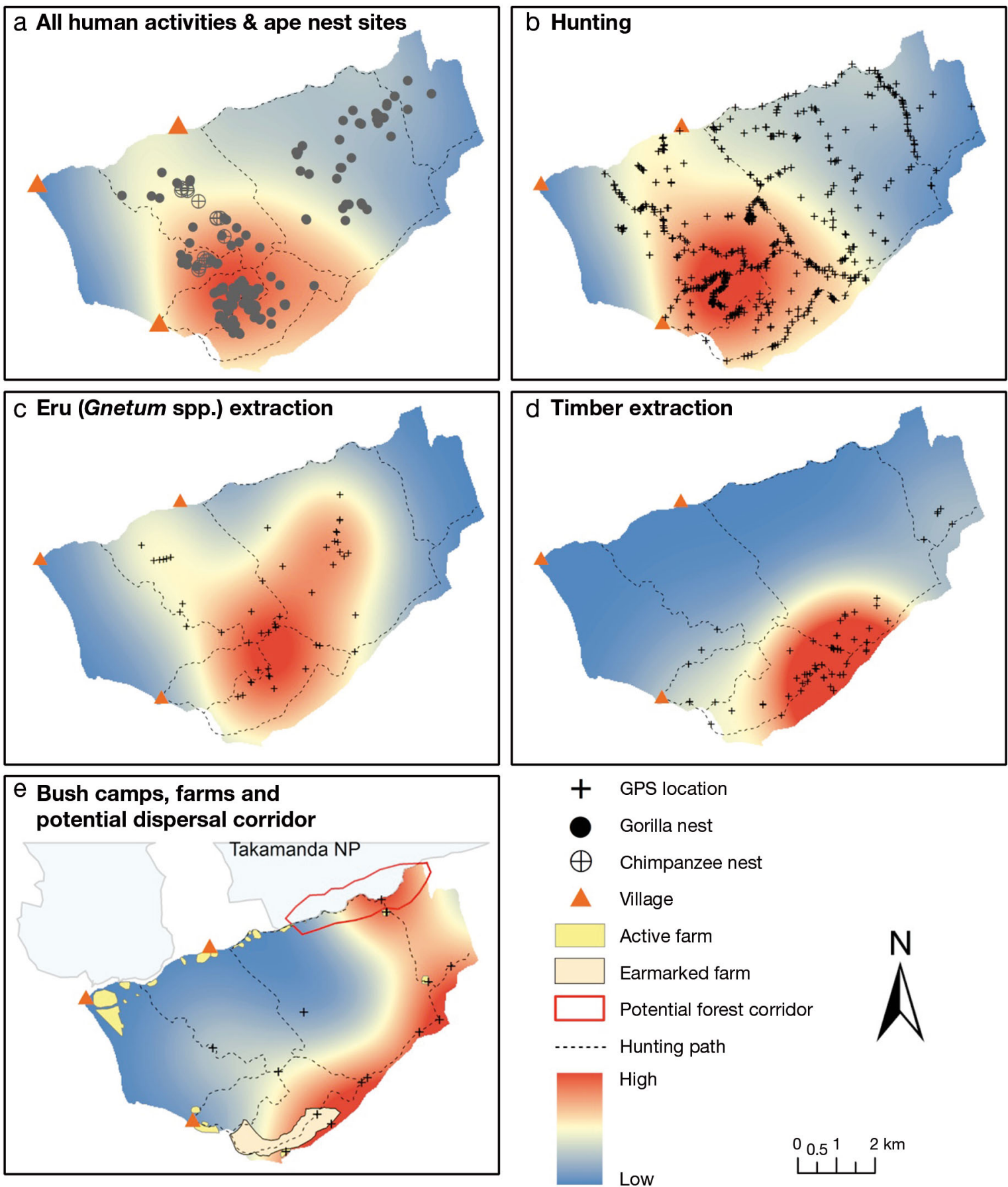

Fig. 4. Kernel density maps of human activity signs recorded during field surveys at Mawambi Hills, southwest Cameroon, in 2010. Colours indicate the gradient in human activity intensity ranging from blue (low) to red (high): (a) all human activities overlaid with great ape nest-site locations, (b) hunting (spent cartridges and active wire snares), (c) eru extraction, (d) timber extraction, and (e) hunting camps and farms, also showing the potential forest corridor linking Mawambi Hills and Takamanda National Park. GPS locations of human signs were used to estimate the kernel functions

sity of human activity (Fig. 4a). Because of its close proximity to the forest, hunters from Awuri can easily access the forest, carry out their hunting activities, and return to their village within $1 \mathrm{~d}$.
During the study period, 231 locations of gorilla nests and 15 locations of chimpanzee nests were found and recorded. The distribution of these nests within the study area is shown in Fig. $4 \mathrm{a}$, and it 
becomes evident that the area of intense human activity coincides with the location of ape nests. The majority of both the gorilla nest sites $(83 \%)$ and the chimpanzee nest sites $(71 \%)$ occurred in the areas of most intense human activity.

Hunting pressure increased with increasing distance from Takpe village (Fig. 4b). Eru harvesting was the most widespread activity (Fig. 4c). Furthermore, eru extraction was only evident when conducted on a large scale, e.g. if the vine was cut or pulled to the ground or if the tree on which the vine grew was felled, and is therefore likely to be underrepresented. The harvesting of other NTFPs, such as njangsang and bush mango, was not detectable as fruits are gathered from the forest floor and transported to temporary camps for further processing; harvesting signs do not remain. Timber extraction was confined to areas adjacent to the Ebe River (Fig. 4d) and was mostly carried out when water levels were sufficiently high to allow timber to be floated out of the area. Bush camps were mostly located in the low-altitude areas close to rivers (Fig. 4e). Farms were located close to settlements. During the study period, a large forest area (110 ha) was marked for conversion to cocoa plantation (Fig. 4e).

\section{Seasonal access to NTFPs}

Human activities occur at $\mathrm{MH}$ throughout the year but mostly during the wet months. Snaring dominates between June and October (Fig. 5). The peak for collecting eru leaves is in December, while hunting peaks during the rainy season, particularly in the month of July.

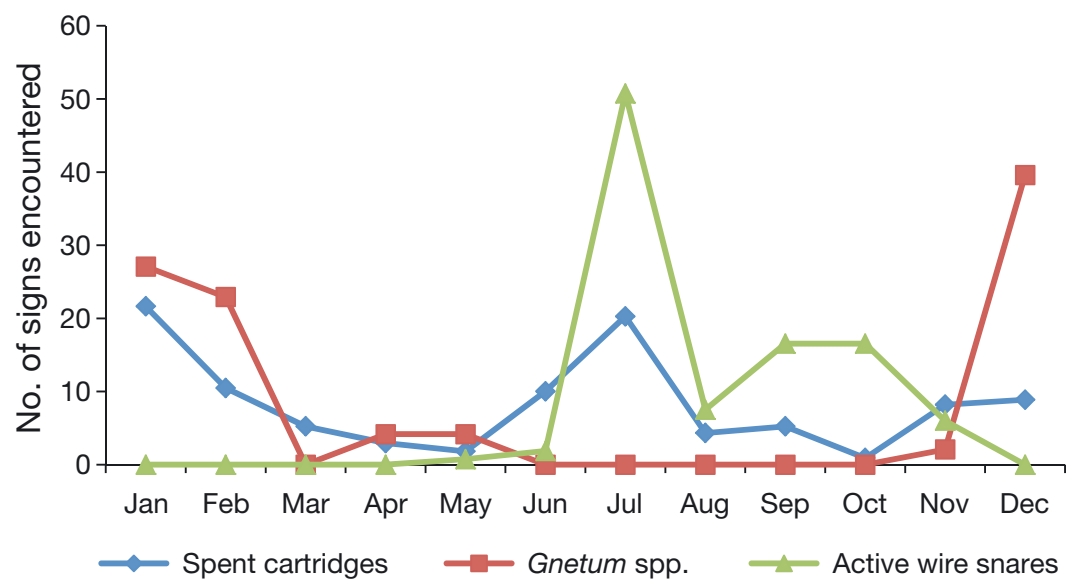

Fig. 5. Seasonal influence on hunting, snaring and the extraction of eru Gnetum spp. from Mawambi Hills, southwest Cameroon

\section{DISCUSSION}

We present the case of forest-dependent communities living in an important wildlife habitat, whose livelihoods centre on farming $(96 \%)$ and the exploitation of NTFPs $(51 \%)$. Livestock or food-crop farming is carried out predominantly for subsistence purposes, and NTFPs constitute the main source of income. Similar to Van Vliet (2010), we found that forest-to-farm conversions are on the rise at $\mathrm{MH}$. Major land conversions are yet to be seen (see Fig. 4e), but most of the people interviewed expressed the desire to expand existing cocoa farms or open new farms. This renewed interest can be attributed to improved transportation and access and the attractive prices of cash crops, such as cocoa and oil palm (Van Vliet 2010). The leaves of Gnetum spp. (eru) are the most harvested NTFP at MH. Forty percent of the households interviewed said they visit the forest at least once a week in search of eru leaves, and up to $80 \%$ of households are involved in eru collection at least once every 2 mo. According to village records, a total of 158 bags (each of 100 bundles) of eru were harvested from MH in 2010 and sold at US\$ 60 per bag, thus generating an average household annual income of US\$179. The peak period for the collection of eru leaves is in December as communities look for money to cover end-of-year festivities. Unlike bush mango Irvingia spp. and njangsang Ricinodendron heudelotii, whose harvests depend on the seasonal fruiting cycle of the plant and interannual variations, harvesting of eru takes place year round and hence is the most reliable source of income for most households. In addition to its commercial uses, eru is an important source of household protein and is regularly consumed, especially during festive periods, as observed elsewhere in Cameroon and Nigeria (Aveling 2009, Ingram et al. 2012), and is suggested to have medicinal properties (Jiofack et al. 2008). To prevent the depletion of this valuable resource, harvesters must be discouraged from poor harvesting methods, such as uprooting and destruction of useful trees that provide support to the plant (Ticktin 2004, Ingram \& Schure 2010). Community-based cultivation efforts of eru have proved successful elsewhere in Cameroon (Sunderland et al. 2002) and, if encouraged at $\mathrm{MH}$, might help ease the pressure from wild harvesting (Shiembo et al. 1996).

As found in studies conducted else- 
where in Africa, bush-meat harvesting at $\mathrm{MH}$ is highly commercialized; $>80 \%$ of bush-meat is harvested for commercial rather than subsistence purposes (de Merode et al. 2004, Kümpel 2006, Wright \& Priston 2010). Gorillas and chimpanzees were actively hunted at $\mathrm{MH}$ until recently (the last reported hunting incident was in 1998). Whilst there was no indication during the present study that they are still being hunted, hunting remains a real risk given the high rate of human activities at the site and the spatial overlap with gorilla nest construction. More than 2060 wire snares were placed at MH by 19 snare hunters in 2009 to capture terrestrial mammals. This means that the encounter rate of wire snares in 2009 was 48 snares per $\mathrm{km}^{2}$. With such a high rate of snaring, gorillas and chimpanzees are at risk of injury, crippling, infection, or death (Waller \& Reynolds 2001). Fig. 3 indicates that duikers and porcupines are the primary targets of bush-meat hunters. Duikers are often assumed to be relatively resilient to hunting pressures (Newing 2001), but studies suggest that throughout West and Central Africa, levels of hunting are already unsustainable (Fa et al. 1995, Wilkie \& Carpenter 1999, Bennett 2002). Hunting is a year-round activity, but the peak in this area occurred during the rainy season (Fig. 5), particularly in the month of July, when more people camp in the forest to collect bush mango seeds and spend the night hunting. Snaring also peaks in the wet season when animal tracks are easily detectable and the soil is damp enough to enable traps to be set. Timber extraction was confined to areas adjacent to the Ebe River (Fig. 4d). Hausa sticks are harvested intensively once every 3 to $4 \mathrm{yr}$, to allow regeneration. The exploitation of hausa sticks was not mentioned by the respondents as an important income source. The reason for this is that harvesting is done by non-indigenous Hausa and Fulani men from neighbouring Nigerian communities who stay in the villages for up to 2 mo and intensively search the forest for mature stems of this species. These harvesters pay a token amount (US\$ 10 per bundle of 50 to 60 sticks; see Fig. S1 in the supplement) to the village council. Through discussion with villagers, it came to light that they were unaware of the market value of the resource and simply accept the small amounts harvesters are willing to pay.

NTFP harvesting at MH seems to have increased in recent years with the village of Awuri serving as the main entry and exit point for most resource users. Previous assessment of human activities at $\mathrm{MH}$ and in neighbouring CRG sites found that $\mathrm{MH}$ experiences a higher rate of human disturbance than TNP and the Mawne forest reserve (Sunderland-Groves et al. 2003, Ekinde \& Warren 2007, Mboh \& Warren 2007). This difference can be attributed to the fact that $\mathrm{MH}$ is relatively less hilly, hence more accessible, than most CRG sites. A lack of basic social services often places significant pressure on local communities and has been linked to unsustainable exploitation of biodiversity (Ikpa et al. 2009). Informal discussions with village chiefs revealed that recent conservation and development activities in the area, notably the creation of TNP in 2008 (decree no. 2008/2751/PM) and the building of a motor-bike road to link the study villages to larger centres and markets, have led to a significant increase in hunting and NTFP harvesting in the area. Although the management plan for TNP is not yet actively enforced, village people have been informed of restrictions on farming and other human activities. Consequently, they are intensifying their exploitation of available land outside the park, which includes MH (Van Vliet 2010, d'Auvergne 2010).

An increase in the rate of NTFP harvesting does not seem to have significantly improved the living conditions of these village communities. Although people are harvesting more resources, they are still not able to make a tangible profit from the resulting income. First, they lack the marketing skills and information to gain leverage in the market and avoid unfair trading practices. For example, the prices of most forest products are set by the traders and not the village-level buyers or sellers, who are not aware of the market value of their wares. This situation makes them vulnerable to exploitation by retailers who are better informed about the value of these resources. A market information system that establishes a flow of information about markets and products between collectors and traders has been proven to have a significant impact on rural NTFP-based economies (Binayee 2005). Secondly, many NTFPs, such as bush mango and njangsang, are seasonal, and harvesting depends on natural growth and regeneration, making their productivity unpredictable and unreliable. Finally, there are no storage and preservation facilities in the villages, meaning that produce must be sold immediately, and the sellers cannot benefit from price rises in times of scarcity.

Areas of high human activity spatially coincide with areas favoured for nesting by endangered great apes (Fig. 4), demonstrating the potential for human activity to influence ape ecology or behaviour. Primates tend to be absent or at low densities in heavily hunted areas (Oates et al. 2000, Maisels et al. 2001, Isaac \& Cowlishaw 2004) and great ape signs tend 
to be inversely correlated with human disturbance (Remis 2000, Laurance et. al. 2006, Kühl et al. 2008, Stokes et al. 2010). At Lope, in Gabon, gorillas appeared to be absent from areas close to human settlement and disturbed secondary forests, avoiding roads and plantations (Tutin \& Fernandez 1984, White \& Tutin 2001). The effect of human activities on wildlife might not be instantaneous (Findlay \& Bourdages 1999), and population decline might only become evident years later after an initial time-lag (Junker et al. 2012); as human-induced pressures at $\mathrm{MH}$ may constitute a relatively recent phenomenon, the high human activity in areas favoured by great apes for nesting may well eventually lead to altered ape ranging patterns (Morgan \& Sanz 2007), increased psychological stress (Boesch 2008), and increased susceptibility to human diseases (Leendertz et al. 2006). In addition, there remains the risk that gorillas and chimpanzees could again be targeted by hunters, and for such large-bodied, slowreproducing species existing at small numbers within the parts of the site most visited by humans, this could result in rapid extirpation. Furthermore, although areas currently most affected by farming do not coincide with the core range of gorillas or chimpanzees, in 2010, 110 ha of forest in the core nesting range of gorillas was earmarked for conversion into an oil palm plantation (Fig. 4e), an initiative which will have considerable impact on the endangered great apes in the site.

\section{CONCLUSION AND RECOMMENDATIONS}

Wildlife species found in unprotected forests face the direct pressure of human disturbance as well as indirect pressures resulting from human modification of their habitats (Olupot et al. 2009). The 3 village communities living at $\mathrm{MH}\left(43 \mathrm{~km}^{2}\right)$ have a combined human population of $\sim 400$ inhabitants. Under such low population pressure, extractive activities may be sustainable (Stromayer \& Ekobo 1991). However, evidence from the present study suggests that the forest is exposed to sustained anthropogenic pressures, which might be a recent phenomenon. Over-exploitation of NTFPs constitutes a threat to the local wildlife as well as to the people who depend on the resources for food and income. Despite its small size, its unprotected status, and the high level of human activities, $\mathrm{MH}$ is a very important great ape habitat with a CRG population comparable to those found in larger protected areas, such as the neighbouring TNP (e.g. MH supports an estimated gorilla population of 20 to 30 weaned gorillas compared to 25 to 45 in TNP; Oates et al. 2007). To maintain long-term availability of NTFPs for the local economy, while reducing the potential pressure on great apes, it is important to limit dependence on forest resources. This can be achieved by providing acceptable incentives or alternative livelihood opportunities (Balint 2006) and encouraging community participation in conservation (Brown et al. 2008), approaches that are recommended for successful biodiversity conservation (Daily \& Ellison 2002, Viña et al. 2007, Illukpitiya \& Yanagida 2010). Although success stories are rare (Theile \& Wiebelt 1994, Arnold \& Ruiz Pérez 2001), promoting alternative livelihoods may be very effective in reducing forest dependence, especially in areas where habitat conversion is not the main form of disturbance (DeFries et al. 2007). In this light, it is important to investigate the possibility of forest-based employment opportunities, such as beekeeping. In Cameroon, beekeeping has been developed and promoted extensively as an alternative to hunting and NTFP collection, and there are cases where investment in beekeeping has been linked to reduced dependence on forest resources (Ingram \& Njikeu 2011, J. H. Wright pers. comm.). It is possible that with proper NGO and government support, beekeeping could also play an important role in reducing pressure on other forest resources at $\mathrm{MH}$. Additionally, on-farm domestication of important NTFPs, such as bush mango, if encouraged, may improve agricultural efficiency and further reduce pressures on the forests (Caviglia-Harris \& Sills 2005, Illukpitiya \& Yanagida 2008, 2010).

A long-term great ape management strategy for $\mathrm{MH}$ must include a land-use system that is acceptable to the local communities. Without some form of protection, there is no guarantee that $\mathrm{MH}$ will not become a target for large-scale oil palm plantations, a trend that is being observed throughout the region (D. N. Etiendem pers. obs.). Also, given the already substantial proportion of land designated as protected in the southwest region of Cameroon, it is unlikely that attempts to legally define new areas or extend existing ones will be supported by the government at the moment. The Cameroon wildlife law does provide for community-based forest management schemes ('community forestry'), which enable communities to legally secure rights to use and sustainably manage their surrounding forest resources, and includes provisions to maximize livelihood benefits and protect biodiversity (Djeukam 2004). While 
the success of community forestry as a tool for conservation and livelihood improvement is not guaranteed (Yufanyi Movuh 2012), it is a legislatively possible option at $\mathrm{MH}$, and there is evidence suggesting that community forests are economically profitable and can play an effective role in forest conservation (Beauchamp \& Ingram 2011, Porter-Bolland et al. 2011).

Information on ape density, distribution, and ranging in response to human activity should be gathered to define core areas and further assess the impact on CRG and NCC populations at this site in order to guide conservation efforts. Also, active investment in great ape conservation education, wildlife law enforcement, local monitoring and research capacities, and support to existing projects, such as the gorilla guardian programme (Nicholas 2009), will guarantee that the species is protected in the short term while buying time for the development of long-term conservation strategies. Although great ape tourism in this site is discouraged because $\mathrm{MH}$ does not meet the rigorous IUCN criteria for establishing and managing ape tourism projects (Macfie \& Williamson 2010), it may be useful to seek and promote opportunities for local people to benefit from eco-tourism that is not directly aimed at gorillas or chimpanzees. $\mathrm{MH}$ remains loosely connected to TNP through an unprotected, unofficial forest corridor to the northeast. Efforts to protect this corridor are constrained by the expansion of farming activities from Takpe village but will ultimately determine the genetic survival of gorillas and chimpanzees at this site (Bergl et al. 2012, d'Auvergne 2010); preserving this corridor is therefore recommended as critical to the survival of the CRG. Furthermore, these recommendations for $\mathrm{MH}$ can be applied to other unprotected CRG and NCC sites in Cameroon and Nigeria. While landscape multi-site strategies have been recommended to ensure viability of both species (Oates et al. 2007, Morgan et al. 2011), site-specific measures developed in close collaboration with local people will drive the conservation agenda, particularly in unprotected forests.

Acknowledgements. We are grateful to the Cameroon government and the traditional authorities for permission to work in the Mawambi Hills. This study was funded by a grant from the National Geographic Conservation Trust (C160/2008) administered by Wildlife Conservation SocietyCameroon Biodiversity Programme, and the Gorilla Foundation. The Flemish Institutional University Cooperation granted D.N.E. an ICP-PhD scholarship during the course of the study.

\section{LITERATURE CITED}

Ainge L, Brown N (2004) Bush mango (Irvingia gabonensis and Irvingia wombolu). In: Clark LE, Sunderland TCH (eds) The key non-timber forest products of central Africa: state of the knowledge. Tech Pap No. 122, US Agency for International Development, Washington, DC

Ames M (1999) Assessing the profitability of forest-based enterprises. In: Wollenberg A, Ingles E (eds) Incomes from the forest: methods for the development and conservation of forest products for local communities. CIFOR, Bogor, Indonesia, p 107-136

Arnold JEM, Ruiz Pérez M (2001) Can non-timber forest products match tropical forest conservation and development objectives? Ecol Econ 39:437-447

Aveling C (2009) The contribution of biodiversity to the maintenance of forest goods and services. In: de Wasseige C, Devers D, de Marcken P, Eba'a Atyi R, Nasi R, Mayaux $P$ (eds) The forests of the Congo Basin - state of the forest 2008. Publication Office of the European Union, Luxembourg, p 159-172

Baddeley A, Turner R (2005) Spatstat: an R package for analyzing spatial point patterns. J Stat Softw 12:1-42

Balint PJ (2006) Improving community-based conservation near protected areas: the importance of development variables. Environ Manag 38:137-148

Beauchamp E, Ingram V (2011) Impacts of community forests on livelihoods in Cameroon: lessons from two case studies. Int Rev 13:389-403

> Bennett EL (2002) Is there a link between wild meat and food security? Conserv Biol 16:590-592

Bergl RA, Oates JF, Fotso R (2007) Distribution and protected area coverage of endemic taxa in West Africa's Biafran forests and highlands. Biol Conserv 134:195-208

Bergl RA, Warren Y, Nicholas A, Dunn A, Imong I, Sunderland-Groves JL, Oates JF (2012). Remote sensing analysis reveals habitat, dispersal corridors and expanded distribution for the Critically Endangered Cross River gorilla Gorilla gorilla diehli. Oryx 46:278-289

Binayee SB (2005) Market information system. An overview of agriculture marketing systems in South Asia. FAO TCP project on Marketing System Development for NWFPs, Lao PDR

Blom AR, Van Zalinge E, Mbea I, Heitkönig MA, Prins HHT (2004) Human impact on wildlife populations within a protected Central African forest. Afr J Ecol 42:23-31

Boesch C (2008) Why do chimpanzees die in the forest? The challenges of understanding and controlling for wild ape health. Am J Primatol 70:722-726

Boot RGA, Gullison RE (1995) Approaches to developing sustainable extraction systems for tropical forest products. Ecol Appl 5:896-903

Brown M, Bonis-Charancle JM, Mogba Z, Sundararajan R, Warne R (2008) Linking the community options analysis and investment toolkit (COAIT), Consensys ${ }^{\circledR}$ and payment for environmental services (PES): a model to promote sustainability in African gorilla conservation. In: Stoinski TS, Steklis HD, Mehlman PT (eds) Conservation in the 21st century: gorillas as a case study. Springer, New York, NY, p 205-227

> Caviglia-Harris JL, Sills EO (2005) Land use and income diversification: comparing traditional and colonist populations in the Brazilian Amazon. Agric Econ 32:221-237

d'Auvergne LS (2010) Assessment of an unprotected forest corridor for the dispersal of isolated Cross-River gorilla 
and Nigeria-Cameroon chimpanzee populations in Southwest Cameroon. MSc dissertation, Oxford Brookes University, Oxford

Daily G, Ellison K (2002) The new economy of nature: the quest to make conservation profitable. Island Press, Washington, DC

de Merode E, Homewood K, Cowlishaw G (2004) The value of bush-meat and other wild foods to rural households living in extreme poverty in Democratic Republic of Congo. Biol Conserv 118:573-581

DeFries R, Hansen AJ, Turner BL II, Reid R, Liu J (2007) Land use change around protected areas: management opportunities to balance human needs and ecological function. Ecol Appl 17:1031-1038

Djeukam R (2004) The wildlife law as a tool for protecting threatened species in Cameroon. Ministry of Environment and Forestry, Yaoundé

> Dumbrell AJ, Clark EJ, Frost GA, Randell TE, Pitchford JW, Hill JK (2008) Changes in species diversity following habitat disturbance are dependent on spatial scale: theoretical and empirical evidence. J Appl Ecol 45:1531-1539

Ekinde A, Warren Y (2007) The proposed Takamanda National Park: Cross River gorilla surveys FebruaryMay 2007. Wildlife Conservation Society and KfW, Report 1 in the July 2007 series. Wildlife Conservation Society (WCS) - Takamanda Mone Landscape Project, Limbe, Cameroon. Available at http://apes.eva.mpg. de/eng/reports.php

Fa JE, Juste J, Perez de Val J, Castroviejo J (1995) Impact of market hunting on mammal species in Equatorial Guinea. Conserv Biol 9:1107-1115

> Fa JE, Peres CA, Meeuwig J (2002) Bush-meat exploitation in tropical forests: an intercontinental comparison. Conserv Biol 16:232-237

Fa JE, Ryan SF, Bell DJ (2005) Hunting vulnerability, ecological characteristics and harvest rates of bush-meat species in afrotropical forests. Biol Conserv 121:167-176

> Findlay CST, Bourdages J (1999) Response time of wetland biodiversity to road construction on adjacent lands. Conserv Biol 14:86-94

> Gillespie TR, Chapman CA, Greiner EC (2005) Effects of logging on gastrointestinal parasite infections and infection risk in African primates. J Appl Ecol 42:699-707

Ikpa T, Dera B, Jande J (2009) Biodiversity conservation: Why local inhabitants destroy habitat in protected areas. Sci World J 4:22-27

Illukpitiya P, Yanagida JF (2008) Role of income diversification in protecting natural forests: evidence from rural households in forest margins of Sri Lanka. Agrofor Syst 74:51-62

Illukpitiya P, Yanagida JF (2010) Farming vs forests: tradeoff between agriculture and the extraction of non-timber forest products. Ecol Econ 69:1952-1963

Ingram V, Schure J (2010) Review of non timber forest products (NTFPs) in Central Africa: Cameroon. CIFOR, Yaoundé

Ingram V, Njikeu J (2011) Sweet, sticky, and sustainable social business. Ecol Soc 16:37

Ingram $\mathrm{V}$, Ndoye $\mathrm{O}$, Iponga DM, Tieguhong JC, Nasi R (2012) Non-timber forest products: contribution to national economy and strategies for sustainable management. In: de Wasseige C, de Marcken P, Bayol N, Hiol Hiol $\mathrm{F}$ and others (eds) The forests of the Congo Basinstate of the forest 2010. Publications office of the European Union, Luxembourg, p 137-154
Isaac NJB, Cowlishaw G (2004) How species respond to multiple extinction threats. Proc R Soc Lond B Biol Sci 271:1135-1141

Jiofack T, Fokunang C, Kemeuze V, Fongnzossie E and others (2008) Ethnobotany and phytopharmacopoea of the south-west ethnoecological region of Cameroon. J Med Plants Res 2:197-206

Junker J, Blake S, Boesch C, Campbell G and others (2012) Recent decline in suitable environmental conditions for African great apes. Divers Distrib 18:1077-1091

Kar SP, Jacobson MG (2012) Market constraints in NTFP trade: household perspectives in Chittagong Hill Tracts of Bangladesh. Int For Rev 14:50-61

Kühl H, Maisels F, Ancrenaz M, Williamson EA (2008) Best practice guidelines for surveys and monitoring of great ape populations. IUCN SSC Primate Specialist Group (PSG), Gland

Kümpel NF (2006) Incentives for sustainable hunting of bushmeat in Rio Muni. PhD thesis, Imperial College, London

Lahm SA (2001) Hunting and wildlife in north eastern Gabon: why conservation should extend beyond park boundaries. In: Weber W, White LJT, Vedder A, Naughton-Treves N (eds) African rain forest ecology and conservation. Yale University Press, New Haven, CT, p 344-354

Laurance WF, Croes BM, Tchignoumba L, Lahm SA and others (2006) Impacts of roads and hunting on central African rainforest mammals. Conserv Biol 20:1251-1261

> Leendertz FH, Pauli G, Maetz-Rensing K, Boardman W and others (2006) Pathogens as drivers of population declines: the importance of systematic monitoring in great apes and other threatened mammals. Biol Conserv 131: 325-337

Macfie EJ, Williamson EA (2010) Best practice guidelines for great ape tourism. IUCN/SSC Primate Specialist Group, Gland. Available at http://data.iucn.org/dbtw-wpd/ edocs/ssc-op-038.pdf (accessed 14 June 2011)

Maisels F, Keming E, Kemei M, Toh C (2001) The extirpation of large mammals and implications for montane forest conservation: the case of the Kilum-Ijim Forest, Northwest Province, Cameroon. Oryx 35:322-331

Mboh H, Warren Y (2007) Large mammal survey of the proposed Takamanda National Park. Unpublished report. Wildlife Conservation Society and KfW. Report 2 in the July 2007 series. Wildlife Conservation Society - Takamanda-Mone Landscape Project, Limbe, Cameroon. Available at http://apes.eva.mpg.de/eng/reports.php

Michon G, de Foresta H (1997) Agroforests: pre-domestication of forest trees or true domestication of forest ecosystems? Neth J Agric Sci 45:451-462

Morgan BJ, Adeleke A, Bassey T, Bergl R and others (2011) Regional action plan for the conservation of the NigeriaCameroon chimpanzee (Pan troglodytes ellioti). IUCN/ SSC Primate Specialist Group \& Zoological Society of San Diego, CA. Available at www.ellioti.org/ActionPlan/ English/elliotiAP-mediumres.pdf (accessed 14 January 2012)

Morgan D, Sanz C (2007) Best practice guidelines for reducing the impact of commercial logging on great apes in western equatorial Africa. IUCN SSC Primate Specialist Group (PGS), Gland. Available at http://data.iucn.org/ dbtw-wpd/edocs/SSC-OP-034.pdf (accessed 14 June 2011)

Newing H (2001) Bush-meat hunting and management: implications of duiker ecology and interspecific competition. Biol Conserv 10:99-118 
Nicholas A (2009) Gorilla guardians gain momentum. Gorilla J 39:12-14

Nicholas A, Warren Y, Bila S, Ekinde A, Ikfuingei R, Tampie $\mathrm{R}$ (2010) Successes in community-based monitoring of Cross River gorillas (Gorilla gorilla diehli) in Cameroon. Afr Primates 7:55-60

Oates JF, Abedi-Lartey M, McGraw WS, Struhsaker TT, Whitesides GH (2000) Extinction of a West African red colobus monkey. Conserv Biol 14:1526-1532

Oates JF, Bergl R, Linder JM (2004) Africa's gulf of guinea forests: biodiversity patterns and conservation priorities. Adv Appl Biodiversity Sci 6:9-91

Oates JF, Sunderland-Groves J, Bergl RA, Dunn A and others (2007) Regional action plan for the conservation of the Cross River gorilla (Gorilla gorilla diehli). IUCN/ SSC Primate Specialist Group and Conservation International, Arlington, VA

Olupot W, Barigyira R, Chapman CA (2009) The status of anthropogenic threat at the people-park interface of Bwindi Impenetrable National Park, Uganda. Environ Conserv 36:41-50

Peters CM (1994) Sustainable harvest of non-timber plant resources in tropical moist forest: an ecological primer. WWF, Washington, DC

Plenderleith K (2004) Njansang (Ricinodendron heudelotii subsp. africanum). In: Clark LE, Sunderland TCH (eds) The key non-timber forest products of central Africa: state of the knowledge. Tech Pap No. 122, US Agency for International Development, Washington, DC, p 63-86

Porter-Bolland L, Ellis EA, Guariguata M, Ruiz-Mallén I, Negrete-Yankelevich S, Reyes-García V (2012) Community managed forests and forest protected areas: an assessment of their conservation effectiveness across the tropics. For Ecol Manag 268:6-17

Remis MJ (2000) Preliminary assessment of the impacts of human activities on gorillas (Gorilla gorilla gorilla) and other wildlife at Dzanga-Sangha Reserve, Central African Republic. Oryx 34:56-65

SCBD (Secretariat of the Convention on Biological Diversity) (2011) Livelihood alternatives for the unsustainable use of bush-meat. Report prepared for the CBD Bush-meat Liaison Group. Tech Ser No. 60. SCBD, Montreal, p 46

Scholte P (2009) At the interface of legislation and wildlife management: a decade of experience with consensual protected area management planning in Cameroon. J Int Wildl Law Policy 12:1-32

Shiembo P, Newton A, Leaky R (1996) Vegetative propagation of Gnetum africanum welw., a leafy vegetable from West Africa. J Hortic Sci 71:149-155

Stokes EJ, Strindberg S, Bakabana PC, Elkan PW and others (2010) Monitoring great ape and elephant abundance at large spatial scales: measuring effectiveness of a conservation landscape. PLoS ONE 5:e10294

Stromayer KAK, Ekobo A (1991) Biological surveys of SE Cameroon. Wildlife Conservation International, New York, NY

Sunderland TH, Besong S, Ayeni JSO (2002) Distribution, utilisation and sustainability of the non-timber forest products of the Takamanda forest reserve, Cameroon. A consultancy report for the project: 'Protection of the forests around Akwaya' (PROFA). GTZ PROFA, Cameroon

Sunderland-Groves JL, Maisels F, Ekinde A (2003) Surveys of Cross River gorilla and chimpanzee populations in Takamanda Forest Reserve, Cameroon. In: Comiskey JA, Sunderland TCH, Sunderland-Groves JL (eds) Takamanda: the biodiversity of an African rainforest. SI/MAB Series 8. Smithsonian Institution, Washington, DC, p 129-140

Theile R, Wiebelt M (1994) Policies to reduce tropical deforestation and degradation: a computable general equilibrium analysis for Cameroon. Q J Int Agric 33: 162-178

$>$ Ticktin T (2004) The ecological implications of harvesting non-timber forest products. J Appl Ecol 41:11-21

Tutin CEG, Fernandez M (1984) Nationwide census of gorilla (Gorilla g. gorilla) and chimpanzee (Pan t. troglodytes) populations in Gabon. Am J Primatol 6:313-336

Van Vliet N (2010) Participatory vulnerability assessment in the context of conservation and development projects: a case study of local communities in Southwest Cameroon. Ecol Soc 15(2):6

Viña A, Bearer S, Chen X, He G and others (2007) Temporal changes in giant panda habitat connectivity across boundaries of Wolong Nature Reserve, China. Ecol Appl 17:1019-1030

> Waller JC, Reynolds V (2001) Limb injuries resulting from snares and traps in chimpanzees (Pan troglodytes schweinfurthii) of the Budongo Forest, Uganda. Primates 42:135-139

Walsh PD, Tutin CEG, Oates JF, Baillie JEM and others (2008) Gorilla gorilla. In: IUCN Red list of threatened species. Version 2011.2. (accessed 21 December 2012)

White LJT, Tutin CEG (2001) Why chimpanzees and gorillas respond differently to logging: a cautionary tale from Gabon. In: Weber W, White L, Naughton-Treves L (eds) African rain forest ecology and conservation: an interdisciplinary perspective. Yale University Press, New Haven, CT, p 449-462

Willcox AS, Nambu DM (2007) Wildlife hunting practices and bush-meat dynamics of the Banyangi and Mbo people of Southwestern Cameroon. Biol Conserv 134: 251-261

Wilkie DS, Carpenter JF (1999) Bush-meat hunting in the Congo Basin: an assessment of impacts and options for mitigation. Biodivers Conserv 8:927-955

Wright JH, Priston NEC (2010) Hunting and trapping in Lebialem Division, Cameroon: bush-meat harvesting practices and human reliance. Endang Species Res 11: 1-12

Yufanyi Movuh MC (2012) The colonial heritage and postcolonial influence, entanglements and implications of the concept of community forestry by the example of Cameroon. For Policy Econ 15:70-77 